ARTICLE

DOI: $10.1038 / s 41467-018-04312-7$

\title{
Instability of the Northeast Greenland Ice Stream over the last 45,000 years
}

Nicolaj K. Larsen ${ }^{1,2}$, Laura B. Levy ${ }^{3}$, Anders E. Carlson ${ }^{4}$, Christo Buizert (1) ${ }^{4}$, Jesper Olsen ${ }^{5}$, Astrid Strunk (1) ${ }^{1}$, Anders A. Bjørk (1D ${ }^{2,6} \&$ Daniel S. Skov ${ }^{1}$

The sensitivity of the Northeast Greenland Ice Stream (NEGIS) to prolonged warm periods is largely unknown and geological records documenting such long-term changes are needed to place current observations in perspective. Here we use cosmogenic surface exposure and radiocarbon ages to determine the magnitude of NEGIS margin fluctuations over the last 45 kyr (thousand years). We find that the NEGIS experienced slow early Holocene ice-margin retreat of 30-40 $\mathrm{ma}^{-1}$, likely as a result of the buttressing effect of sea-ice or shelf-ice. The NEGIS was $\sim 20-70 \mathrm{~km}$ behind its present ice-extent $\sim 41-26 \mathrm{ka}$ and $\sim 7.8-1.2 \mathrm{ka}$; both periods of high orbital precession index and/or summer temperatures within the projected warming for the end of this century. We show that the NEGIS was smaller than present for approximately half of the last $\sim 45 \mathrm{kyr}$ and is susceptible to subtle changes in climate, which has implications for future stability of this ice stream.

\footnotetext{
${ }^{1}$ Department of Geoscience, Aarhus University, Aarhus 8000, Denmark. ${ }^{2}$ Centre for GeoGenetics, Natural History Museum, University of Copenhagen, Copenhagen 1350, Denmark. ${ }^{3}$ Department of Geology, Humboldt State University, Arcata, 95521 CA, USA. ${ }^{4}$ College of Earth, Ocean, and Atmospheric Sciences, Oregon State University, Corvallis, 97331 OR, USA. ${ }^{5}$ Department of Physics and Astronomy, Aarhus University, Aarhus 8000 , Denmark.

${ }^{6}$ Department of Earth System Science, University of California, Irvine, 92697 CA, USA. Correspondence and requests for materials should be addressed to N.K.L. (email: nkl@geo.au.dk)
} 
G reenland Ice Sheet (GrIS) mass loss has doubled since the beginning of the 20th century ${ }^{1}$. A prominent feature of the GrIS is the Northeast Greenland Ice Stream (NEGIS $^{2,3}$, which constitutes an $\sim 600$-km-long ice stream that drains $\sim 12 \%$ of the interior GrIS via three fast-flowing marineterminating outlet glaciers: Nioghalvfjerdsfjord Gletscher (NG), Zachariae Isstrøm (ZI), and Storstrømmen Gletscher (SG) (Fig. 1). From 2006 to 2012, the NG and ZI accelerated and retreated after more than a decade of stability ${ }^{4}$. ZI accelerated further in 2012 when its ice velocity tripled, losing its residual ice shelf ${ }^{5}$. Presently, ZI is rapidly retreating along a reverse-sloped marine-based bed, whereas NG is retreating slower along an upward-sloping bed ${ }^{5}$. In contrast, SG is at present relatively stable and in a phase of buildup ${ }^{4}$ following its 1978-1984 surge ${ }^{6}$. Modeling studies of NEGIS using different warming scenarios suggest that NG will not change significantly, whereas ZI will continue fast and unstoppable retreat $30 \mathrm{~km}$ upstream of its current position, contributing $\sim 16.2 \mathrm{~mm}$ to global-mean sea-level rise by 2100 C.E. ${ }^{7}$. Then the ice margin will stabilize on a topographic ridge unless frontal summer melt rates exceed $6 \mathrm{~m}$ day $^{-1}$, which would trigger further inland retreat; this is a forcing that is within the range of the possible Intergovernmental Panel on Climate Change (IPCC) scenarios ${ }^{7}$. To assess these modern observations and modeling scenarios, as well as the possibilities of future NEGIS collapse, a long-term perspective is urgently needed to understand the (in)stability of the NEGIS.

During the global Last Glacial Maximum (LGM; 26-19 ka), the GrIS reached the continental shelf in Northeast Greenland, but it has been contentious whether it reached the shelf edge $\sim 250-350 \mathrm{~km}$ from the present ice margin or remained on the inner shelf (Fig. 1a) ${ }^{8}$. High-resolution multibeam swath bathymetry and shallow seismic data from the shelf offshore of the NEGIS show a number of glacial landforms including megascale glacial lineations suggesting that the ice sheet margin extended to the shelf edge in Northeast Greenland ${ }^{9-12}$. The age of the landforms is, however, poorly constrained due to a lack of marine sediment cores from the area. It is assumed that they were formed during the LGM as they appear fresh and are not draped with significant sediment cover. Farther north at $81^{\circ} \mathrm{N}$, the reduction in ice-rafted debris and lower sedimentation rates in marine sediment cores suggest that deglaciation from the shelf began $\sim 20 \mathrm{ka}^{13}$, whereas the shelf areas at Kejser Franz Josef Fjord $\left(72^{\circ} \mathrm{N}\right)$ and Scoresby Sund $\left(70^{\circ} \mathrm{N}\right) \sim 700-1000 \mathrm{~km}$ farther south experienced regional deglaciation $\sim 17-19 \mathrm{ka}^{8,14-17}$. Radiocarbon dates of postglacial marine shells from the coastline outside NEGIS indicate deglaciation around 9.7-9.1 ka; the later deglaciation of this area compared to adjacent areas to the north and south has been used to suggest more extensive glaciation reaching the shelf edge ${ }^{18}$. However, these ${ }^{14} \mathrm{C}$ dates are only minimum-limiting ages, which are often significantly younger than ${ }^{10} \mathrm{Be}$ ages of deglaciation in Greenland ${ }^{19}$. These limitations highlight the need for better age constraints to resolve the longterm ice-margin fluctuations of NEGIS.

Here we combine cosmogenic surface exposure ages $\left({ }^{10} \mathrm{Be}\right)$ on glacial boulders with radiocarbon dates $\left({ }^{14} \mathrm{C}\right)$ from reworked marine shells in moraines to reconstruct the last 45 kyr of NEGISmargin fluctuations (see Methods). In addition, we investigate the climate forcings that may drive long-term ice-margin variability on these time scales. We find that the NEGIS experienced slow early Holocene ice-margin retreat of $30-40 \mathrm{~m} \mathrm{a}^{-1}$ from the outer coast to the present ice margin, likely as a result of the buttressing effect of sea or shelf ice. We furthermore show that the NEGIS
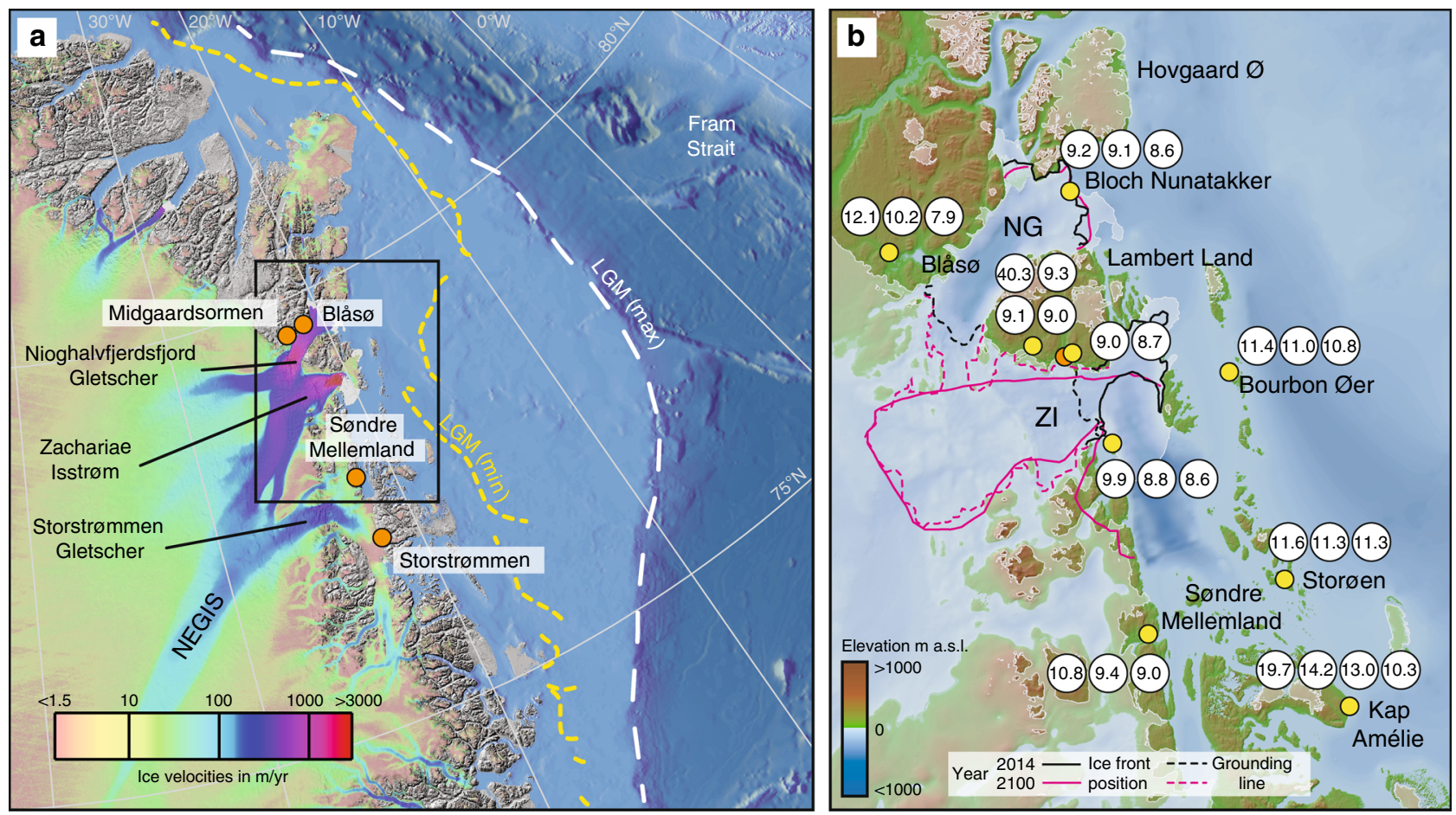

Fig. 1 Field location of the Northeast Greenland Ice Stream. a Map with minimum and maximum LGM ice extent ${ }^{8}$, and velocity map of the inland ice ${ }^{69}$. Orange circles are sites with existing ${ }^{14} \mathrm{C}$ dates reworked in Little Ice Age moraines or from raised marine deposits presently dammed by NEGIS ${ }^{27,28}$. $\mathbf{b}$ Inset map with bed topography, merged from existing topographic and bathymetric data with mass conservation (beneath grounded ice) and gravity inversion (beneath floating ice and open ocean) ${ }^{70}$. Outline of glacier margin is based on GIMP data ${ }^{71}$. The observed and modeled ice front and grounding line positions in 2014 C.E. and under maximum melting scenarios in 2100 C.E. ${ }^{7}$. New cosmogenic surface exposure ages (yellow circles) in ka (thousand years ago) from outer coast and proximal to the present ice margin in Northeast Greenland $78^{\circ} \mathrm{N}$ to $80^{\circ} \mathrm{N}$. Red circles mark new ${ }^{14} \mathrm{C}$ dates of reworked shell fragments from a moraine on Lambert Land 
was smaller than present $\sim 41-26 \mathrm{ka}$ and $\sim 7.8-1.2 \mathrm{ka}$, or approximately half of the last $\sim 45 \mathrm{kyr}$ as a result of air and ocean temperature forcings similar to or slightly higher than present.

\section{Results}

The timing of early Holocene ice retreat. Cosmogenic exposure dating is a widely used method to constrain the timing of deglaciation in Greenland ${ }^{19-25}$. In this study, we use twenty-eight ${ }^{10} \mathrm{Be}$ boulder ages to constrain the NEGIS retreat from the coastline to the present-day ice margin $(60-100 \mathrm{~km})$ in Northeast Greenland $\left(77.4-79.4^{\circ} \mathrm{N}\right.$ ) during the last deglaciation (Fig. 1a, b). By assuming that the deglaciation of the outer coast to present ice margin was largely synchronous within the study site, we calculated the mean and standard error of the mean for ${ }^{10} \mathrm{Be}$ ages at the coast and present ice margin (Methods and Supplementary Table 1 and Table 2). At the three coastal sites on Bourbon Øer, Storøen, and Kap Amélie, ten samples were dated. After excluding one outlier, we calculated a mean ${ }^{10} \mathrm{Be}$ age of $11.7 \pm 0.4$ (0.6) ka (uncertainty in parentheses includes the production rate uncertainty). Adjacent to the present ice margins at Blåsø, Lambert Land, ZI, Søndre Mellemland, and Bloch Nunatakker we dated eighteen samples. With one outlier excluded, we obtained a mean deglaciation age of $9.3 \pm 0.2(0.4) \mathrm{ka}$. Our ${ }^{10} \mathrm{Be}$ ages demonstrate that the deglaciation of the outer coast to present ice margin, a distance of $60-100 \mathrm{~km}$, was completed within $\sim 2.4 \mathrm{kyr}$ at an average retreat rate of $30-40 \mathrm{~m} \mathrm{a}^{-1}$.

The response of the NEGIS to a warmer climate. Radiocarbon dating of reworked marine material (shells or whale bones) in moraines is a method often used to infer times when the ice margins in Greenland were further inland than at present ${ }^{26-29}$. We have combined new and existing ${ }^{14} \mathrm{C}$ dates from NEGIS's three marine terminating outlet glaciers in the study area (Fig. 1a, b). Overall, there are two periods where the ${ }^{14} \mathrm{C}$ dates show that the NEGIS was smaller than present during Marine Isotope Stage 3 (MIS 3) and the Holocene (Figs. 2 and 3). We present eight new ${ }^{14} \mathrm{C}$ dates from Lambert Land adjacent to ZI ranging from $41.1 \pm$ 0.5 to $26.3 \pm 0.2 \mathrm{ka}$ (Fig. $3 \mathrm{~b}$, Supplementary Table 3 ) that show that ZI retreated at least $\sim 20 \mathrm{~km}$ inland from its 2014 position opening up for marine conditions farther inland. Four existing ${ }^{14} \mathrm{C}$ dates from moraines adjacent to SG show that it was smaller than present at least $37.0 \pm 1.0$ to $28.4 \pm 0.3 \mathrm{ka}$ and open marine conditions extended at least $\sim 40 \mathrm{~km}$ farther inland relative to present ${ }^{28}$. Based on the distribution of ${ }^{14} \mathrm{C}$ ages from ZI and SG, it can be concluded that the NEGIS was continually retracted at least $20-40 \mathrm{~km}$ behind the present ice extent prior to $\sim 41 \mathrm{ka}$ and until after $\sim 26 \mathrm{ka}$. Previously published radiocarbon dates of reworked shells and whale bones in Little Ice Age moraines and raised marine deposits likewise suggest that NEGIS was $\sim 20-70$ $\mathrm{km}$ farther inland than today $\sim 7.8-1.2 \mathrm{ka}$, before it advanced to its Little Ice Age maximum in the 19th century ${ }^{27,28}$.

\section{Discussion}

Our new ${ }^{10} \mathrm{Be}$ ages demonstrate that deglaciation of the outer coast to the present ice margin occurred between $11.7 \pm 0.6$ and $9.3 \pm 0.4 \mathrm{ka}$. This is $\sim 2 \mathrm{kyr}$ older than the oldest recorded ${ }^{14} \mathrm{C}$ dates of $\sim 9.7 \mathrm{ka}$ from the outer coast ${ }^{18}$. The timing of early Holocene NEGIS retreat from the coast to its current extent generally coincides with both increased surface air and subsurface ocean temperatures (Fig. 2a-d). Summer surface air temperature reconstructed by merged ice-core data and climate models shows an abrupt rise in temperature at the Younger Dryas termination, coeval with the ${ }^{10} \mathrm{Be}$ ages presented here for initial ice retreat from the coastline, followed by gradual warming to peak temperatures $\sim 10-9$ ka (Fig. 2 d $)^{30,31}$. In the Fram Strait, subsurface ocean warming is recorded slightly later $\sim 10.8-10.1 \mathrm{ka}$, at a rate of $\sim 0.5^{\circ} \mathrm{C}$ per century and a peak Holocene temperature of $\sim 6{ }^{\circ} \mathrm{C}$ at $\sim 10.1 \mathrm{ka}^{32}$ (Fig. 2c). We suggest that the combined effect of insolation-driven atmospheric/oceanic warming and abrupt atmospheric warming at the end of the Younger Dryas likely triggered NEGIS coastal to inland retreat.

The mean ${ }^{10} \mathrm{Be}$ ages suggest that the deglaciation from the outer coast to the present ice margin occurred at a retreat rate of $30-40 \mathrm{~m} \mathrm{a}^{-1}$. This estimate is slower than early Holocene retreat rates of $\sim 100 \mathrm{~m} \mathrm{a}^{-1}$ for Jakobshavn Isbræ in West Greenland ${ }^{25}$ and $\sim 80 \mathrm{~m} \mathrm{a}^{-1}$ for Helheim Glacier in Southeast Greenland ${ }^{21}$. It is striking that the marine-based parts of NEGIS only experienced moderate rates of ice retreat compared to other major GrIS outlet glaciers ${ }^{21,25}$. We attribute this to the buttressing effect of sea ice or shelf ice ${ }^{33}$, which was hinged on to islands off the coast in Northeast Greenland (Fig. 1) until $\sim 9.5 \mathrm{ka}^{34,35}$.

The ${ }^{14} \mathrm{C}$ ages of reworked shells demonstrate that the NEGIS was retracted $\sim 20-40 \mathrm{~km}$ during MIS 3 from $\sim 41$ to $\sim 26 \mathrm{ka}$ when ice-core data indicate that the mean-annual temperature was generally as cold as the LGM and accumulation rates (and therefore ice flow velocities) were 4-5 times slower than during the Holocene ${ }^{36}$ (Fig. 3g, h). However, as glaciers respond primarily to summer air temperatures ${ }^{37}$, we estimate local summer air temperatures at our site during MIS 3 using a multipleregression method (see Methods). Approximately 41-26 ka estimated summer temperatures were $\sim 6-8{ }^{\circ} \mathrm{C}$ warmer than the LGM primarily because of higher boreal summer insolation, but $\sim 8-12^{\circ} \mathrm{C}$ colder than the preindustrial period (Fig. 3c). The combination of relatively mild summers and low snow accumulation rates (Fig. $3 \mathrm{c}, \mathrm{g}$ ) seems to be a plausible explanation for the retracted NEGIS margin during MIS 3 . The ${ }^{14} \mathrm{C}$ dates from MIS 3 also provide a maximum age constraint for when the NEGIS began its advance toward its LGM position and show that the GrIS in this sector was larger than present after $\sim 26$ ka until $9.3 \pm$ $0.4 \mathrm{ka}$ (uncertainty including the production rate uncertainty), when the ${ }^{10} \mathrm{Be}$ ages indicate that the areas in front of the present ice margin were again deglaciated. The timing of maximum LGM extent of NEGIS agrees with a Northeast Greenland marine record that places the ice margin on the continental shelf $\sim 26-20$ $\mathrm{ka}^{13}$.

Published ${ }^{14} \mathrm{C}$ dates of marine shells and whale bones from the left-lateral margin of NG show that the floating ice margin was smaller than present extent and reached a minimum of at least 70 $\mathrm{km}$ behind its present extent $\sim 7.8-4.6 \mathrm{ka}^{27}$. At SG, reworked shells in Little Ice Age moraines suggest that it was smaller than present $\sim 5.4-1.2 \mathrm{ka}^{28}$. The timing of the retracted ice margin of the NEGIS outlet glaciers $\sim 7.8-1.2 \mathrm{ka}$ generally agrees with a smaller than present GrIS extent during the mid-Holocene thermal maximum seen in southern Greenland ${ }^{38}$. The timing of retracted NEGIS also coincides with local chironomid-based temperature maxima $\sim 8-5$ ka from Store Koldeway in Northeast Greenland $^{39}$ and warm subsurface temperatures in Fram Strait ${ }^{32}$ (Fig. 2c, e). However, it is also concurrent with relatively high accumulation rates ${ }^{36}$, suggesting that the forcing of the midHolocene NEGIS retreat differs from that of MIS 3. Both periods of retracted NEGIS margins occurred during, or just after, periods of high orbital precession index (Fig. 3d-f), supporting the notion that precession forcing dominates the ice-sheet response on orbital time scales.

We compare our results with a recent state-of-the art modeling study, which suggests that the NG is difficult to destabilize when compared to the ZI and that bed topography plays a critical role in determining ice-margin responses to ocean warming ${ }^{7}$. The three-dimensional ice-sheet model is forced by constant surface mass balance and variable ocean forcing. It predicts that NG will likely keep its current configuration with the grounding line and 


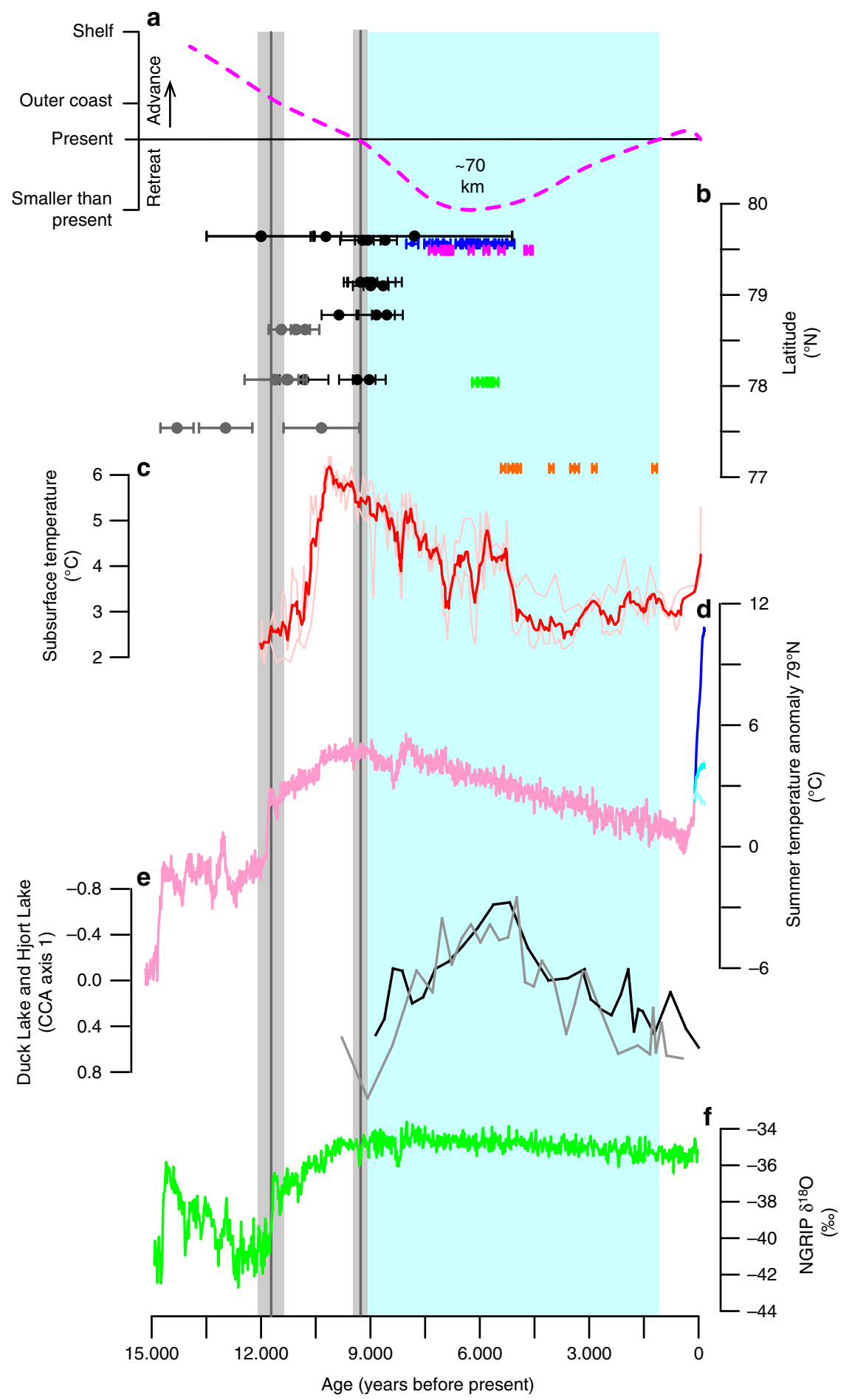

Fig. 2 Ice fluctuations and climate variability the last $15 \mathrm{kyr}$. a Reconstruction of ice-margin fluctuations based on $\mathbf{b}{ }^{10}$ Be ages with external uncertainties from outer coast (dark gray) and outside the Little Ice Age moraine (black), and ${ }^{14} \mathrm{C}$ dates from raised marine deposits presently dammed by NEGIS up to $70 \mathrm{~km}$ upstream the present ice margin at NG; Blåsø (blue $)^{27}$ and Midgaardsormen (pink) ${ }^{27}$, and ${ }^{14} \mathrm{C}$ dates of reworked shells in Little Ice Age moraines at Søndre Mellemland (green) ${ }^{27}$, and at SG (orange) ${ }^{28}$. Vertical gray bars are the mean and standard error of the outer (older) and inner (younger) ${ }^{10} \mathrm{Be}$ ages with the production rate uncertainty included. Vertical light blue bar is when the NEGIS is smaller than present. The early Holocene ice-retreat coincides with c peak subsurface temperatures based on planktic foraminiferal fauna assemblages (SST100) $)^{32}$ and $\mathbf{d}$ peak summer temperature (JJA) (pink) at $79^{\circ} \mathrm{N}$ with RCP 2.6 (light blue), 4.5 (blue), and 8.5 scenarios (dark blue) ${ }^{31}$. e The timing of maximum mid-Holocene ice retreat coincides with local chironomidbased temperature maxima at Duck (black) and Hjort (grey) lakes on Store Koldeway in Northeast Greenland ${ }^{39}$. f Ice core $\delta^{18} \mathrm{O}$ record from NGRIP72 


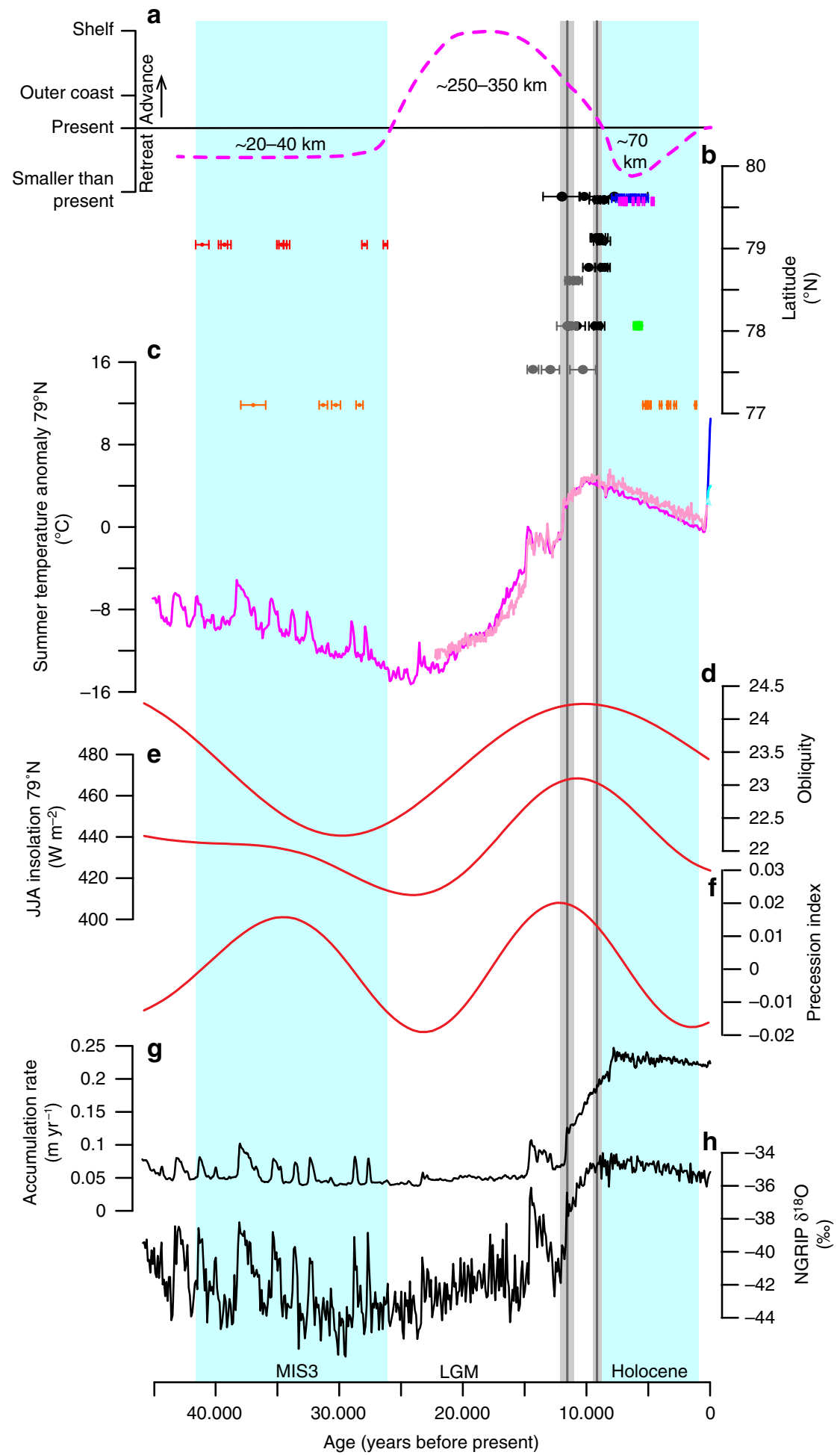

Fig. 3 Ice and climate fluctuations of the Northeast Greenland Ice Stream for the last 45 kyr. a Reconstruction of ice-margin fluctuations based on $\mathbf{b}{ }^{10}$ Be ages with external uncertainties from outer coast (dark gray) and outside the Little Ice Age moraine (black), and ${ }^{14} \mathrm{C}$ dates from raised marine deposits presently dammed by NEGIS up to $70 \mathrm{~km}$ upstream the present ice margin at NG; Blåsø (blue) ${ }^{27}$ and Midgaardsormen (pink) ${ }^{27}$, and ${ }^{14} \mathrm{C}$ dates of reworked shells in Little Ice Age moraines at Søndre Mellemland (green) ${ }^{27}$, and at SG (orange) ${ }^{28}$. Vertical gray bars are the mean and standard error of the outer (older) and inner (younger) ${ }^{10} \mathrm{Be}$ ages with the production rate uncertainty included. Vertical light blue bars are when the NEGIS is smaller than present. c Reconstructed summer temperature (pink) with RCP 2.6 (light blue), 4.5 (blue), and 8.5 scenarios (dark blue) at $79^{\circ} \mathrm{N}^{31}$ and a summer temperatures reconstruction (magenta) based on a multiple-regression method (see Methods). d-f Orbital parameters and summer insolation at $79^{\circ} \mathrm{N}$. $\mathbf{g}$ Accumulation rate at NEEM ${ }^{36}$. h Ice core $\delta^{18} \mathrm{O}$ record from NGRIP ${ }^{72}$ 
the ice front close to its present location by 2100 C.E., even when the model is forced with high basal-melt rates and frontal-melt rates (Fig. 1b). Conversely, ZI is modeled to be more sensitive, with the simulations showing $\sim 30 \mathrm{~km}$ ice-margin retreat before stabilization on a topographic ridge by 2100 C.E. unless frontal summer melt rates exceed $6 \mathrm{~m}$ day $^{-1}$. This would trigger further inland retreat and the oceanic forcing is within the range of possible future scenarios ${ }^{7}$. The geologic data clearly demonstrate that both NG and ZI, as well as SG, retreated behind their present extents during the Holocene. These observations suggest that the model underestimates the sensitivity of NEGIS, and particularly the NG, to increased oceanic forcing. However even when the grounding line and ice velocity are stable, once the ice margin reaches a topographic ridge neither NG nor ZI reach a steady state and still lose mass over the entire duration of the simulation $^{7}$. They could eventually retreat further inland on a longer time scale as demonstrated by the geological record.

In conclusion, we show that the NEGIS experienced major icemargin fluctuations over the last $\sim 45 \mathrm{kyr}$, ranging from $\sim 250$ to $350 \mathrm{~km}$ of ice advance beyond its present position during the LGM to $\sim 20-40 \mathrm{~km}$ ice retreat behind its present extent during MIS 3 and $\sim 70 \mathrm{~km}$ during the mid-Holocene. During the last $\sim 45$ kyr, the NEGIS was smaller than present at least half of the time. These observations present two scenarios that can drive NEGIS retreat within its current extent. Over the early Holocene, the instability of the largely marine-based NEGIS margin was triggered by a combination of air and ocean temperatures similar to today or within the projected scenarios (RCP4.5 to RCP8.5) for the end of this century (Fig. 2d). In contrast, the NEGIS retraction during MIS 3 was potentially due to a combination of lower accumulation/ice flow, elevated incident shortwave radiation, and attendant summer air temperature warming. Our results demonstrate that the NEGIS has responded sensitively to past climatic changes and that its current extent is an anomaly rather than the norm for the last $\sim 45 \mathrm{kyr}$. These new geologic observations suggest that the NEGIS will continue to undergo icemargin retreat and lose mass given the ongoing Arctic warming ${ }^{40}$ combined with the topographic setting of large deep fjords ${ }^{41}$ that allow subsurface water to reach and destabilize the ice front ${ }^{4,5,7}$.

\begin{abstract}
Methods
Study area. The study area comprises the northern part of the East Greenland Caledonides and the bedrock is primarily composed of crystalline basement except for a few places on Lambert Land and north of Nioghalvfjerdsfjorden, where it is overlain by Paleoprotozoic or Proterozoic sediments ${ }^{42}$. Topographic relief ranges between 0 and $500 \mathrm{~m}$ but locally mountains are up to $\sim 1000 \mathrm{~m}$ high. The landscape is characterized by selective linear erosion; signs of glacial erosion are significant, particularly at lower elevations. During the LGM, the ice sheet advanced on to the continental shelf in Northeast Greenland ${ }^{43-45}$, but it has been contentious whether it reached the shelf edge $\sim 250-350 \mathrm{~km}$ from the present ice margin or remained on the inner shelf (Fig. 1a) $)^{8}$. High-resolution multibeam swath bathymetry and shallow seismic data from the shelf offshore NEGIS show a number of glacial landforms including mega-scale glacial lineations, suggesting that the ice extended all the way the shelf edge in Northeast Greenland ${ }^{9-12}$. According to the existing ${ }^{14} \mathrm{C}$-based deglaciation chronology, the outer coast was deglaciated $\sim 9.7-9.5 \mathrm{ka}^{27}$. Following the deglaciation, the land was inundated with marine limits of $40-60 \mathrm{~m}$ above sea level ${ }^{46}$.
\end{abstract}

Cosmogenic exposure dating. In 2015 and 2016 we conducted fieldwork using helicopter and twin otter plane. We selected field sites using aerial and satellite imagery. Most samples were collected from boulders perched on ice scoured bedrock, except for three samples from Kap Amelié collected from boulders on drift and on Lambert Land where we collected two boulder samples on a moraine outside the Little Ice Age moraine (Fig. 1b). We aimed at sampling glacially abraded boulders on bedrock (Supplementary Fig. 1), with boulders $>1 \mathrm{~m}$ in height and diameter to reduce the influence of snow cover on our resulting ages ${ }^{47}$. We measured shielding, and recorded the latitude and longitude and elevation using a handheld GPS with an uncertainty of $<10 \mathrm{~m}$. The boulder samples were collected using a rock saw. All samples were prepared using carrier "PHE1601" and were measured using the beryllium standard 07KNSTD ${ }^{48}$ at Aarhus AMS Centre (AARAMS). We used the CRONUS-Earth online calculator ${ }^{49}$, the Arctic production rate $\mathrm{e}^{50}$, and time invariant scaling of Lal/Stone $\mathrm{e}^{51,52}$ to calculate sample ages (Supplementary Table 1, Table 2). In addition, we used a rock density of $2.7 \mathrm{~g}$ $\mathrm{cm}^{-3}$ and made no correction for potential snow cover, and surface erosion. The study area has undergone glaciostatic uplift since the deglaciation of $\sim 40 \mathrm{~m}$ at Blåse and $\sim 60 \mathrm{~m}$ at Hovgaard $\emptyset^{46}$, and the sample elevation at the time of collection does not reflect its time-averaged sample elevation history. We calculated samplespecific elevation corrections $\mathrm{s}^{25}$ and found that the uplift corrections are within 1 sigma of the AMS sample uncertainties similar to or lower than what have been calculated for West Greenland where the postglacial uplift was larger ${ }^{24,25}$. As the uplift history in Northeast Greenland is less well constrained compared to West Greenland ${ }^{46}$ and the vertical uncertainty of the GPS measurement is of the same order as the uplift correction, we present ${ }^{10} \mathrm{Be}$ ages without correcting for glaciostatic uplift, similar to most other ${ }^{10} \mathrm{Be}$ studies from Greenland ${ }^{19,20,22,23,53,54}$. We note that the lack of this correction does not significantly change our ${ }^{10} \mathrm{Be}$ ages or our interpretations. Individual ${ }^{10} \mathrm{Be}$ ages are presented with their 1-sigma analytical uncertainties, which include the uncertainty in the blank correction. When we compare our ${ }^{10} \mathrm{Be}$ ages with other climate records we include the production rate uncertainty using the following formula:

$$
\sqrt{\text { Uncertainty }=}
$$

Uncertainty of ${ }^{10}$ Be ages, outer coast $=$

$$
\sqrt{(0.4)^{2}+(11.7 * 0.037)^{2}}=0.6 \mathrm{kyr},
$$

where $0.4=1 \sigma$ standard error of the mean (in kyr), $11.7=$ mean ${ }^{10} \mathrm{Be}$ age (in ka); $0.037=$ the uncertainty associated with the Arctic production rate ${ }^{50}$ and "St" scaling $^{11,52}$.

$$
\begin{gathered}
\text { Uncertainty of }{ }^{10} \text { Be ages, present ice margin }= \\
\qquad \sqrt{(0.2)^{2}+(9.3 * 0.037)^{2}}=0.4 \mathrm{kyr},
\end{gathered}
$$

where $0.2=1 \sigma$ standard error of the mean (in kyr); $9.3=$ mean ${ }^{10} \mathrm{Be}$ age (in ka), $0.037=$ the uncertainty associated with the Arctic production rate ${ }^{50}$ and "St" scaling ${ }^{51,52}$

We excluded two outliers based on the most general knowledge of the regions glacial history that are older than the LGM (GL1519, GL1545) and most likely contain ${ }^{10} \mathrm{Be}$ inherited from a previous period of exposure ${ }^{47}$.

Radiocarbon dating. A number of shell fragments were collected on the surface of a moraine outside the Little Ice Age moraine on Lambert Land. The shell fragments were identified to species level, when possible. Only large pieces from a single specimen were used for dating. In the laboratory, shell fragments were cleaned and leached using $\mathrm{HCl}$ removing c. $25 \%$ of the outer shell. Around $10 \mathrm{mg}$ of material was used for the ${ }^{14} \mathrm{C}$ analysis; all contained enough carbon for AMS radiocarbon measurement. All radiocarbon ages have been calibrated into calendar years using IntCall $3^{55}$ and a reservoir age of 550 years $(\Delta R=150)^{56}$ in Oxcal $4.3^{57}$. The ${ }^{14} \mathrm{C}$ ages are reported with 2-sigma uncertainty (Supplementary Table 3 ).

Temperature reconstruction. Greenland ice cores provide detailed records on the timing and magnitude of past mean-annual temperature change. However, GrIS mass loss occurs during the summer month ${ }^{58}$, and therefore summer (JJA) temperatures are more relevant than mean-annual temperatures when considering past margin positions. For the last $22 \mathrm{kyr}$ Greenland ice core $\delta^{15} \mathrm{~N}$-based temperature reconstructions ${ }^{59}$ were merged with climate model simulations ${ }^{60-62}$ to generate Greenland-wide, seasonally resolving temperature reconstructions ${ }^{31}$. Supplementary Fig. 2a shows the reconstructed mean-annual (ANN), summer (JJA), and winter (DJF) temperatures at our study location $\left(79^{\circ} \mathrm{N}, 20^{\circ} \mathrm{W}\right)$. Coupled ocean atmosphere GCM simulations are not available through MIS 3; therefore the same approach cannot be used to investigate summer temperatures during that time period. Instead, we rely on a multiple regression approach in which it is assumed that three key forcings dominate the Greenland temperature evolution: AMOC strength, greenhouse gas radiative forcing, and local orbital forcing. Summer temperature at the site $\left(T_{\mathrm{JJA}}\right)$ is then given by:

$$
T_{\mathrm{JJA}}=a_{1} \times \mathrm{AMOC}+a_{2} \times 5.35 \ln \frac{p_{\mathrm{CO}_{2}}}{280}+a_{3} \times \Phi_{\mathrm{JJA}}^{79^{\circ} \mathrm{N}},
$$

where AMOC denotes the estimated strength of the overturning in $\mathrm{Sv}, \mathrm{p}_{\mathrm{CO}_{2}}$ is the atmospheric $\mathrm{CO}_{2}$ dry mixing ratio in ppm, $\Phi_{\mathrm{IIA}}^{7 \mathrm{O}^{\circ}}$ is the average solar insolation at $79^{\circ} \mathrm{N}$ north during the months June, July, and August, and $a_{1}$ through $a_{3}$ are linear scaling coefficients. The $\mathrm{CO}_{2}$ mixing ratio is converted to radiative forcing using the approach by ref. ${ }^{63}$, with a pre-industrial reference concentration of $280 \mathrm{ppm}$. All forcings are shown in Supplementary Figs. 2B-D. In reconstructing $T_{\mathrm{JJA}}$, we use a multi-ice core $p_{\mathrm{CO}_{2}}$ compilation ${ }^{64}$, and insolation values calculated following ref. 65 . The AMOC strength is the most uncertain of the three forcings and is reconstructed as follows. We start from the Greenland Summit ${ }^{66,67} \delta^{18} \mathrm{O}$ record (average of GRIP and GISP2 $\delta^{18} \mathrm{O}$ records) corrected for mean ocean $\delta^{18} \mathrm{O}^{68}$, and convert it 
to site (mean annual) temperature using an effective isotope sensitivity of $\alpha=0.29$ $\% \mathrm{~K}^{-159}$. Using the logic underlying Eq. 1, we remove the effect of $\mathrm{CO}_{2}$ forcing $\left(b_{2}=3.05 \mathrm{Km}^{2} \mathrm{~W}^{-1}\right)$ and insolation $\left(b_{3}=0.0481 \mathrm{Km}^{2} \mathrm{~W}^{-1}\right.$ sensitivity to local summer insolation) from the GISP2 temperatures, where the stated (annual mean) sensitivities were obtained from the single-forcing deglacial GCM simulations of ref. ${ }^{61}$, in which greenhouse gas and orbital forcings were applied separately. It is then assumed that remaining temperature variability is due solely to AMOC variability, which we estimate using a sensitivity (mean annual) of $b_{1}=1.07 \pm 0.25$ $\mathrm{K} \mathrm{Sv}^{-1}$, which optimizes the correlation to the reconstruction by ref. ${ }^{31}$, as shown in Supplementary Fig. 2B. The NEGIS MIS 3 summer temperature anomaly is then estimated with Eq. 1 using coefficients $a_{1}=0.238 \pm 0.1 \mathrm{~K} \mathrm{~Sv}^{-1}, a_{2}=3.76 \pm 1.5$ $\mathrm{Km}^{2} \mathrm{~W}^{-1}$, and $a_{3}=0.137 \pm 0.03 \mathrm{Km}^{2} \mathrm{~W}^{-1}$; these coefficients are found using multiple regression analysis on the 0 -22ka NEGIS JJA reconstruction; the coefficients are in good agreement with those found from the single-forcing coupled GCM experiments of ref. ${ }^{61}$. The MIS 3 JJA reconstruction is shown in Supplementary Fig. 2e, together with an uncertainty envelope that was found by adding all stated uncertainties in quadrature. We want to emphasize the large uncertainty inherent in trying to reconstruct both the AMOC and NEGIS summer temperature based on regression techniques-the resulting values should be considered an order-of-magnitude estimate.

Data availability. The data that support the findings of this study are available in the supplementary information or it can be acquired from the corresponding author on request

Received: 19 January 2018 Accepted: 20 April 2018

Published online: 14 May 2018

\section{References}

1. Kjeldsen, K. K. et al. Spatial and temporal distribution of mass loss from the Greenland ice sheet since AD 1900. Nature 528, 396-401 (2015).

2. Joughin, I., Fahnestock, M., MacAyeal, D., Bamber, J. L. \& Gogineni, P. Observation and analysis of ice flow in the largest Greenland ice stream. J. Geophys. Res.: Atmospheres 106, 34021-34034 (2001).

3. Reeh, N., Thomsen, H. H., Higgins, A. K. \& Weidick, A. Sea ice and the stability of north and Northeast Greenland floating glaciers. Ann. Glaciol. 33, 474-480 (2001).

4. Khan, S. A. et al. Sustained mass loss of the Northeast Greenland ice sheet triggered by regional warming. Nat. Climate Change 4, 292-299 (2014).

5. Mouginot, J. et al. Fast retreat of Zachariae Isstrom, Northeast Greenland. Science 350, 1357-1361 (2015).

6. Reeh, N., Bøggild, C. E. \& Oerter, H. Surge if Storstrømmen, a large outlet glacier froom the inland ice of North-East Greenland. Rapp. Grønands Geol. Unders. 162, 201-209 (1994).

7. Choi, Y., Morlighem, M., Rignot, E., Mouginot, J. \& Wood, M. Modeling the response of Nioghalvfjerdsfjorden and Zachariae Isstrøm Glaciers, Greenland, to ocean forcing over the next century. Geophys. Res. Lett. 44, 071-011,079 (2017).

8. Funder, S., Kjeldsen, K. K., Kjær, K. H. \& Ó Cofaigh, C. The Greenland ice sheet during the last 300.000 years: a review. Dev. Quat. Sci. 15, 699-713 (2011).

9. Winkelmann, D., Jokat, W., Jensen, L. \& Schenke, H. W. Submarine end moraines on the continental shelf off NE Greenland - implications for lateglacial dynamics. Quat. Sci. Rev. 29, 1069-1077 (2010).

10. Evans, J., Cofaigh, C. O., Dowdeswell, J. A. \& Wadhams, P. Marine geophysical evidence for former expansion and flow of the Greenland ice sheet across the north-east Greenland continental shelf. J. Quat. Sci. 24, 279-293 (2009).

11. Arndt, J. E., Jokat, W. \& Dorschel, B. The last glaciation and deglaciation of the Northeast Greenland continental shelf revealed by hydro-acoustic data. Quat. Sci. Rev. 160, 45-56 (2017).

12. Arndt, J. E. et al. A new bathymetry of the Northeast Greenland continental shelf: constraints on glacial and other processes. Geochem. Geophys. Geosyst. 16, 3733-3753 (2015).

13. Nørgaard-Pedersen, N., Mikkelsen, N. \& Kristoffersen, Y. Late glacial and Holocene marine records from the independence Fjord and Wandel sea regions, North Greenland. Polar Res. 27, 209-221 (2008).

14. O Cofaigh, C. et al. Timing and significance of glacially influenced masswasting in the submarine channels of the Greenland basin. Mar. Geol. 207, 39-54 (2004).

15. Stein, R., Nam, S.I., Grobe, H. \& Hubberten, H. in Late Quaternary Palaeoceanography of the North Atlantic Margins, Vol. 111 (eds Andrews, J. T. et al.) 135-151 (Special Publication-Geological Society of London, 1996).

16. Nam, S. I., Stein, R., Grobe, H. \& Hubberten, H. Late quaternary glacial interglacial changes in sediment composition at the East Greenland continental-margin and their paleoceanographic implications. Mar. Geol. 122, 243-262 (1995).

17. Evans, J. et al. in Glacier-influenced Sedimentation on High-Latitude Continental Margins, Vol. 203 (eds Dowdeswell, J. A. \& Cofaigh, C. Ó.) 149-179 (Special Publication-Geological Society of London, 2002).

18. Bennike, O. \& Björck, S. Chronology of the last recession of the Greenland ice sheet. J. Quat. Sci. 17, 211-219 (2002).

19. Sinclair, G. et al. Diachronous retreat of the Greenland ice sheet during the last deglaciation. Quat. Sci. Rev. 145, 243-258 (2016).

20. Carlson, A. E. et al. Earliest Holocene South Greenland ice sheet retreat within its late Holocene extent. Geophys. Res. Lett. 41, 5514-5521 (2014).

21. Hughes, A. L. C. et al. Rapid response of Helheim Glacier, Southeast Greenland, to early Holocene climate warming. Geology 40, 427-430 (2012).

22. Larsen, N. K. et al. Rapid early Holocene ice retreat in West Greenland. Quat. Sci. Rev. 92, 310-323 (2014).

23. Rinterknecht, V. et al. Unstable ice stream in Greenland during the Younger Dryas cold event. Geology 42, 759-762 (2014).

24. Young, N. et al. Age of the Fjord Stade moraines in the Disko Bugt region, Western Greenland, and the 9.3 and 8.2 ka cooling events. Quat. Sci. Rev. 60, 76-90 (2013).

25. Young, N. E. et al. Response of Jakobshavn Isbrae Greenland, to Holocene climate change. Geology 39, 131-134 (2011).

26. Weidick, A., Kelly, M. \& Bennike, O. Late quaternary development of the southern sector of the Greenland ice sheet, with particular reference to the Qassimiut lobe. Boreas 33, 284-299 (2004).

27. Bennike, O. \& Weidick, A. Late quaternary history around Nioghalvfjerdsfjorden and Jokelbugten, North-East Greenland. Boreas 30, 205-227 (2001).

28. Weidick, A., Andreasen, C., Oerter, H. \& Reeh, N. Neoglacial glacier changes around Storstrømmen, North-East Greenland. Polarforschung 64, 95-108 (1996).

29. Briner, J. P., Kaufman, D. S., Bennike, O. \& Kosnik, M. A. Amino acid ratios in reworked marine bivalve shells constrain Greenland ice sheet history during the Holocene. Geology 42, 75-78 (2014).

30. Lecavalier, B. S. et al. High Arctic Holocene temperature record from the Agassiz ice cap and Greenland ice sheet evolution. Proc. Natl Acad. Sci. USA 114, 5952-5957 (2017).

31. Buizert, C. et al. Greenland-wide seasonal temperature reconstructions for the last deglaciation. Geophys. Res. Lett. 45, 1905-1914 (2018).

32. Werner, K. et al. Holocene sea subsurface and surface water masses in the Fram Strait - comparisons of temperature and sea-ice reconstructions. Quat. Sci. Rev. 147, 194-209 (2016).

33. Amundson, J. M. et al. Ice melange dynamics and implications for terminus stability, Jakobshavn Isbrae Greenland. J. Geophys. Res.: Earth Surface 115, doi:Artn F01005 10.1029/2009jf001405 (2010).

34. Funder, S. et al. A 10,000-year record of Arctic Ocean sea-ice variability-view from the beach. Science 333, 747-750 (2011).

35. Muller, J., Masse, G., Stein, R. \& Belt, S. T. Variability of sea-ice conditions in the Fram Strait over the past 30,000 years. Nat. Geosci. 2, 772-776 (2009).

36. Rasmussen, S. O. et al. A first chronology for the North Greenland Eemian ice drilling (NEEM) ice core. Climate Past 9, 2713-2730 (2013).

37. Oerlemans, J. Extracting a climate signal from 169 glacier records. Science 308, 675-677 (2005).

38. Larsen, N. K. et al. The response of the Southern Greenland ice sheet to the Holocene thermal maximum. Geology 43, 291-294 (2015).

39. Schmidt, S. et al. Chironomids as indicators of the Holocene climatic and environmental history of two lakes in Northeast Greenland. Boreas 40, 116-130 (2011).

40. IPCC. Climate Change 2013: the Physical Science Basis. 1535 (Cambridge University Press, Cambridge, 2013).

41. Morlighem, M., Rignot, E., Mouginot, J., Seroussi, H. \& Larour, E. Deeply incised submarine glacial valleys beneath the Greenland ice sheet. Nat. Geosci. 7, 418-422 (2014)

42. Higgins, A. K. Descriptive text to the geological map of Greenland, 1:500 000, Lambert land, sheet 9. Geol. Surv. Den. Greenl. Map Ser. 7, 1-32 (2015).

43. Landvik, J. Y. The last glaciation of Germania-Land and adjacent areas, Northeast Greenland. J. Quat. Sci. 9, 81-92 (1994).

44. Hjort, C. Glaciation in Northern East Greenland during the late Weichselian and early Flandrian. Boreas 8, 281-296 (1979).

45. Hjort, C. A glacial chronology for Northern East Greenland. Boreas 10, 259-274 (1981)

46. Lecavalier, B. S. et al. A model of Greenland ice sheet deglaciation based on observations of ice extent and relative sea-level. Quat. Sci. Rev. 102, 54-84 (2014).

47. Gosse, J. C. \& Phillips, F. M. Terrestrial in situ cosmogenic nuclides: theory and application. Quat. Sci. Rev. 20, 1475-1560 (2001).

48. Nishiizumi, K. et al. Absolute calibration of Be-10 AMS standards. Nucl. Instrum. Methods Phys. Res. Sect. B 258, 403-413 (2007). 
49. Balco, G., Stone, J. O., Lifton, N. A. \& Dunai, T. J. A complete and easily accessible means of calculating surface exposure ages or erosion rates from Be10 and Al-26 measurements. Quat. Geochronol. 3, 174-195 (2008).

50. Young, N. E., Schaefer, J. M., Briner, J. P. \& Goehring, B. M. A Be-10 production-rate calibration for the Arctic. J. Quat. Sci. 28, 515-526 (2013).

51. Lal, D. Cosmic-ray labelling of erosion surfaces: in situ nuclide production rates and erosion models. Earth Planet. Sci. Lett. 104, 424-439 (1991).

52. Stone, J. O. Air pressure and cosmogenic isotope production. J. Geophys. Res. 105, 23753-23759 (2000)

53. Larsen, N. K. et al. A younger Dryas re-advance of local glaciers in North Greenland. Quat. Sci. Rev. 147, 47-58 (2016)

54. Schweinsberg, A. D., Briner, J. P., Miller, G. H., Bennike, O. \& Thomas, E. K. Local glaciation in West Greenland linked to North Atlantic Ocean circulation during the Holocene. Geology 45, 195-198 (2017).

55. Reimer, P. J. et al. IntCal13 and Marine13 radiocarbon age calibration curves 0-50,000 years cal BP. Radiocarbon 55, 1869-1887 (2013).

56. Mörner, N.-A. \& Funder, S. C-14 dating of samples collected during teh NORQUA 86expedition, and notes on the marine reservoir effect. Medd. Om Grønl. 22, 57-59 (1990).

57. Ramsey, C. B. Bayesian analysis of radiocarbon dates. Radiocarbon 51, 337-360 (2009).

58. van den Broeke, M. et al. Partitioning recent Greenland mass loss. Science 326, 984-986 (2009).

59. Buizert, C. et al. Greenland temperature response to climate forcing during the last deglaciation. Science 345, 1177-1180 (2014).

60. Liu, Z. et al. Transient simulation of last deglaciation with a new mechanism for Bolling-Allerod warming. Science 325, 310-314 (2009).

61. He, F. et al. Northern Hemisphere forcing of Southern Hemisphere climate during the last deglaciation. Nature 494, 81-85 (2013).

62. Liu, Z. Y. et al. Younger Dryas cooling and the Greenland climate response to CO2. Proc. Natl Acad. Sci. USA 109, 11101-11104 (2012).

63. Myhre, G., Highwood, E. J., Shine, K. P. \& Stordal, F. New estimates of radiative forcing due to well mixed greenhouse gases. Geophys. Res. Lett. 25, 2715-2718 (1998).

64. Bereiter, B. et al. Revision of the EPICA Dome C CO2 record from 800 to 600kyr before present. Geophys. Res. Lett. 42, 542-549 (2015).

65. Berger, A. \& Loutre, M. F. Insolation values for the climate of the last 10000000 years. Quat. Sci. Rev. 10, 297-317 (1991).

66. Johnsen, S. J. et al. Irregular glacial interstadials recorded in a new Greenland ice core. Nature 359, 311-313 (1992).

67. Grootes, P. M., Stuiver, M., White, J. W. C., Johnsen, S. \& Jouzel, J. Comparison of oxygen-isotope records from the Gisp2 and Grip Greenland ice cores. Nature 366, 552-554 (1993).

68. Waelbroeck, C. et al. Sea-level and deep water temperature changes derived from benthic foraminifera isotopic records. Quat. Sci. Rev. 21, 295-305 (2002).

69. Mouginot, J., Rignot, E., Scheuchl, B. \& Millan, R. Comprehensive annual ice sheet velocity mapping using Landsat- 8 , Sentinel-1, and RADARSAT-2Data. Remote Sens. 9, 364 (2017).

70. Morlighem, M. et al. BedMachinev3: complete bed topography and ocean bathymetry mapping of Greenland from multibeam echo sounding combined with mass conservation. Geophys. Res. Lett. 44, 11051-11061 (2017).
71. Howat, I. M., Negrete, A. \& Smith, B. E. The Greenland Ice Mapping Project (GIMP) land classification and surface elevation data sets. Cryosphere $\mathbf{8}$, 1509-1518 (2014)

72. Andersen, K. K. et al. High-resolution record of Northern Hemisphere climate extending into the last interglacial period. Nature 431, 147-151 (2004).

\section{Acknowledgements}

This study has been supported by the Villum Foundation and Arctic Research Centre (ARC) at Aarhus University. A.E.C. and C.B. are supported by U.S. National Science Foundation award OPP-1418074. We thank Svend Funder for identifying the shell fragments from Lambert Land.

\section{Author contributions}

N.K.L. conceived the research; N.K.L., L.B.L., A.S., A.A.B., and D.S.S. conducted the fieldwork in 2015 and 2016; L.B.L., A.S., and J.O. performed the laboratory analysis for ${ }^{10} \mathrm{Be}$ and ${ }^{14} \mathrm{C}$ samples; J.O. measured the ${ }^{10} \mathrm{Be}$ and ${ }^{14} \mathrm{C}$ concentrations on AMS; A.E.C. and C.B. calculated the summer temperature and assisted with the ice and climate analysis; all authors contributed to the final interpretation and writing of the manuscript.

\section{Additional information}

Supplementary Information accompanies this paper at https://doi.org/10.1038/s41467018-04312-7.

Competing interests: The authors declare no competing interests.

Reprints and permission information is available online at http://npg.nature.com/ reprintsandpermissions/

Publisher's note: Springer Nature remains neutral with regard to jurisdictional claims in published maps and institutional affiliations. (c) Open Access This article is licensed under a Creative Commons
Attribution 4.0 International License, which permits use, sharing, adaptation, distribution and reproduction in any medium or format, as long as you give appropriate credit to the original author(s) and the source, provide a link to the Creative Commons license, and indicate if changes were made. The images or other third party material in this article are included in the article's Creative Commons license, unless indicated otherwise in a credit line to the material. If material is not included in the article's Creative Commons license and your intended use is not permitted by statutory regulation or exceeds the permitted use, you will need to obtain permission directly from the copyright holder. To view a copy of this license, visit http://creativecommons.org/ licenses/by/4.0/.

(C) The Author(s) 2018 